Г. М. Шаяхметова ${ }^{1}$, В. М. Коваленко ${ }^{1}$, О. Г. Басовська ${ }^{2}$, А. В. Возна ${ }^{2}$

\title{
Клінічні біохімічні показники сироватки крові здорових статевозрілих білих щурів-самців (ретроспективна оцінка)
}

\author{
'Державна установа «Інститут фармакології та токсикології \\ Національної академії медичних наук України», м. Київ \\ ${ }^{2}$ Навчально-науковий центр «Інститут біології та медицини» \\ Київського національного університету імені Тараса Шевченка, м. Київ
}

Ключові слова: щури, самці, клінічні біохімічні показники, сироватка крові, норма

Діапазон нормальних або очікуваних гематологічних і клінічних біохімічних показників у лабораторних тварин може бути корисним інструментом для інтерпретації результатів токсикологічних досліджень. Однак таку інформацію часто важко знайти. Незважаючи на те, що дані контрольної (інтактної) групи завжди включаються разом 3 даними піддослідних груп до публікацій, часто виникає необхідність перегляду значної кількості наукової літератури для знаходження необхідної інформації. Ці дані, як правило, не є основною темою статті, тому їх важко відшукати за ключовими словами. Більше того, нормальні значення гематологічних $\mathrm{i}$ клінічних біохімічних показників можуть варіювати в різних ліній лабораторних тварин і серед тварин різних розплідників, а також певною мірою залежати від застосованих методів дослідження.

Мета дослідження - ретроспективна оцінка даних клінічної біохімії здорових (контрольні групи) щурів 3 розплідника ДУ «Інститут фармакології та токсикології НАМНУ» .

Матеріали та методи. Для ретроспективної оцінки даних були зібрані та проаналізовані результати дослідження сироватки крові щурів-самців лінії Вістар 311 досліджень, що останніми роками були проведені на базі Ду «Інститут фармакології та токсикології

(C) Колектив авторів, 2019
НАМНУ ». Для аналізу були використані дані, отримані на щурах-самцях, оскільки більшість досліджень була проведена саме на тваринах даної статі.

Усі тварини були надані розплідником експериментально-біологічної клініки ДУ «Інститут фармакології та токсикології НАМНУ». Щурів утримували в стандартних умовах віварію за температури $22-24{ }^{\circ} \mathrm{C}$ і відносної вологості $30-70 \%$, з вільним доступом до корму та води. Використовували корм для лабораторних тварин виробництва ТОВ НТВ «ФУД», Україна.

Щурів розміщували в клітках з полікарбонату розмірами $(660 \times 370 \times 140) \mathrm{Mm}$ 3 кришками з гальванізованої сталі групами по 4-5 тварин. Клітки були забезпечені пластиковими поїлками. Підстилкою слугувала тирса 3 вільхи (Alnus glutinosa), попередньо піддана автоклавуванню.

Забір зразків крові для дослідження проводили в дорослих статевозрілих самців щурів лінії Вістар (Rattus norvegicus) масою 250-350 г, віком 8-12 тижнів.

Плани всіх досліджень були розглянуті та схвалені Комітетом з біоетики ДУ «Інститут фармакології та токсикології НАМНУ » ; усі процедури, пов'язані з гуманним поводженням 3 тваринами та їхнім використанням в експериментах, були дотримані.

У щурів у терміни, обумовлені відповідними протоколами експериментів, натщесерце під легким ефірним наркозом у скляні центрифужні пробірки брали кров із стегнової вени для виділення сироватки для біохімічних 
випробувань. Сироватку крові виділяли після інкубації (37 ${ }^{\circ} \mathrm{C}$ протягом 3 год) центрифугуванням на лабораторній центрифузі ОПН-8 (1500 об/хв, 10 хв).

У сироватці крові на біохімічному аналізаторі Prestige 24і (Японія) досліджували активність аланінамінотрансферази (АлАТ), лужної фосфатази (ЛФ), гамма-глутамілтрансферази (ГГТ), лактатдегідрогенази (ЛДГ), альфа-амілази, а також вміст альбуміну, загального білірубіну, загального холестерину, тригліцеридів, загального білка, глюкози, креатиніну, сечовини, сечової кислоти, хлоридів, фосфору, ліпопротеїдів низької (ЛПНЩ) та високої щільності (ЛПВЩ), використовуючи біотести виробництва фірми «P. Z. Cormay» (Польща) або Futura (Італія).

Статистичну обробку отриманих даних проводили з використанням комп’ютерної програми «Statistica-10.0». Дані надано у вигляді $\mathrm{M} \pm \mathrm{SD}$, де $\mathrm{M}-$ середнє значення, SD - стандартне відхилення від середнього, а також $95 \%$ довірчого інтервалу (95 \% CI).

Результати та їх обговорення. Щури є найчастіше використовуваним в експериментальній біології та медицині видом гризунів. Дослідження на щурах формують базу для обгрунтування ефективності та безпечності лікарських засобів, оцінки токсичності хімічних речовин, що використовуються в індустрії та сільському господарстві, а також для встановлення механізмів їхньої токсичної дії [1]. 3 метою ідентифікації ризиків для людини або інших таргетних видів використовують широкий набір біомаркерів, який включає масу тіла, гематологічні та клінічні біохімічні показники, масу органів, імунологічні показники, мікроскопічну оцінку тканин та ін. [1]. Важливим етапом токсикологічних досліджень є виявлення змін в органах i тканинах за біохімічними показниками сироватки крові та зіставлення їх з гістопатологічними та іншими допоміжними результатами. Клінічні біохімічні показники сироватки крові піддослідних тварин часто $є$ основою для інтерпретації отриманих даних $\mathrm{i}$ рекомендації додаткових тестів [2].

Важливими факторами, які необхідно враховувати за остаточної оцінки отриманих даних, є стандартні умови утримання та розведення тварин, їхній вік і стать. Крім того, повинні бути стандартизовані біологічні ритми, оскільки їхні порушення можуть індукувати зміни вмісту та активності ферментів [3]. Параметри нормального діапазону показників для конкретного виду й лінії лабораторних тварин мають вирішальне значення для встановлення фактичних змін в експериментальних умовах токсикологічного експерименту. Для оцінки фізіологічних відхилень в організмі лабораторних тварин, використаних у фармакологічних i/або токсикологічних дослідженнях in vivo, має бути доступною значна кількість даних [4].

Перш ніж визначити будь-яку патологію в організмі піддослідних тварин слід забезпечити достовірні значення контрольного діапазону. Подібні дані можуть бути отримані від контрольних груп під час кожного дослідження та мають важливе значення для належної оцінки результатів, отриманих в експерименті. Періодичний перегляд історичних даних відіграє ключову роль у забезпеченні якості досліджень з урахуванням стандартних умов утримання тварин і діапазону нормальних значень для популяції тварин, що використовуються кожною конкретною лабораторією [3].

Метою цієї публікації $€$ надання дослідникам у галузі фармакології та токсикології та всім, хто використовує в експериментальній роботі щурів, діапазону нормальних або очікуваних значень для обраних параметрів сироватки крові, отриманих у різні терміни від здорових (контрольних) тварин у 11 дослідженнях. Вважається, що різні аналітичні методи, а також змінні, пов'язані з навколишнім середовищем $\mathrm{i}$ технікою, впливають на значення, встановлені для конкретного параметра. Оскільки дані, наведені в цій публікації, були отримані ідентичним засобом тестування, а тварини походять 3 одного джерела, то певні ризики були мінімізовані.

Для ретроспективного аналізу були обрані найважливіші клінічні біохімічні показники сироватки крові, які 
віддзеркалюють функціональний стан різних органів і систем $[2,5,6]$. Відповідні дані біохімічних досліджень здорових (норма) щурів-самців лінії Вістар з розплідника експериментально-біологічної клініки ДУ «Інститут фармакології та токсикології НАМНУ п підсумовано в таблиці.

Таблиця

Клінічні біохімічні показники сироватки крові здорових дорослих щурів-самиів лінї̈ Вістар з розплідника експериментально-біологічної клініки ДУ «Інститут фармакологї̈ та токсикологї̈ НАМНУ"

\begin{tabular}{|c|c|c|c|c|c|c|}
\hline Показник & $\begin{array}{c}\text { Одиниці } \\
\text { вимірю- } \\
\text { вання } \\
\end{array}$ & Метод & $\mathbf{N}$ & $\mathbf{M}$ & SD & $95 \% \mathrm{Cl}$ \\
\hline Альбумін & г/л & $\begin{array}{l}\text { Колориметричний (з бром- } \\
\text { крезоловим зеленим) }\end{array}$ & 95 & 39,81 & 5,71 & $\begin{array}{c}38,65- \\
40,98\end{array}$ \\
\hline $\begin{array}{l}\text { Загальний } \\
\text { білок }\end{array}$ & г/л & $\begin{array}{l}\text { Колориметричний (біуре- } \\
\text { товий) }\end{array}$ & 95 & 69,45 & 9,45 & $\begin{array}{c}67,53- \\
71,38 \\
\end{array}$ \\
\hline $\begin{array}{l}\text { Загальний } \\
\text { білірубін }\end{array}$ & мкмоль/л & Колориметричний (DPD) & 75 & 1,23 & 1,17 & $\begin{array}{c}0,96- \\
1,50\end{array}$ \\
\hline $\begin{array}{l}\text { Тригліце- } \\
\text { риди }\end{array}$ & ммоль/л & $\begin{array}{l}\text { Колориметричний ензима- } \\
\text { тичний TRINDER }\end{array}$ & 90 & 0,69 & 0,63 & $\begin{array}{c}0,56- \\
0,82\end{array}$ \\
\hline $\begin{array}{l}\text { Холесте- } \\
\text { рин }\end{array}$ & ммоль/л & $\begin{array}{l}\text { Однореагентний колориме- } \\
\text { тричний ензиматичний } \\
\text { TRINDER } \\
\end{array}$ & 95 & 1,51 & 0,41 & $\begin{array}{c}1,42- \\
1,59\end{array}$ \\
\hline лпВщ & ммоль/л & Ензиматичний прямий & 51 & 0,573 & 0,32 & $\begin{array}{c}0,48- \\
0,66\end{array}$ \\
\hline лПНЩ & ммоль/л & Ензиматичний прямий & 51 & 0,335 & 0,12 & $\begin{array}{c}0,30- \\
0,37\end{array}$ \\
\hline Глюкоза & ммоль/л & $\begin{array}{l}\text { Колориметричний ензима- } \\
\text { тичний TRINDER }\end{array}$ & 95 & 6,16 & 2,35 & $\begin{array}{c}5,68- \\
6,63\end{array}$ \\
\hline Креатинін & мкмоль/л & $\begin{array}{l}\text { Колориметричний кінетич- } \\
\text { ний Яффе (без депротеїні- } \\
\text { зації) }\end{array}$ & 90 & 45,16 & 10,29 & $\begin{array}{l}43,0- \\
47,31\end{array}$ \\
\hline Сечовина & ммоль/л & $\begin{array}{l}\text { Ензиматичний уреазний } \\
\text { GLDH }\end{array}$ & 94 & 6,67 & 1,81 & $\begin{array}{l}6,30- \\
7,04 \\
\end{array}$ \\
\hline $\begin{array}{l}\text { Сечова } \\
\text { кислота }\end{array}$ & ммоль/л & $\begin{array}{l}\text { Колориметричний ензима- } \\
\text { тичний TRINDER }\end{array}$ & 33 & 152,75 & 36,61 & \begin{tabular}{|c|}
$139,77-$ \\
165,73 \\
\end{tabular} \\
\hline АлАТ & $\mathrm{MO} / л$ & $\begin{array}{l}\text { Кінетичний УФ (без піри- } \\
\text { доксаль фосфату) IFCC }\end{array}$ & 95 & 55,37 & 17,35 & $\begin{array}{c}51,84- \\
58,90\end{array}$ \\
\hline лдг & $\mathrm{MO} / ת$ & $\begin{array}{l}\text { Колориметричний ензима- } \\
\text { тичний УФ (IFCC/SFBC) }\end{array}$ & 95 & 1995,67 & 543,29 & \begin{tabular}{|l}
$1885,0-$ \\
2106,35
\end{tabular} \\
\hline ГГТ & $\mathrm{MO} / ת$ & $\begin{array}{l}\text { Колориметричний кінетич- } \\
\text { ний }\end{array}$ & 87 & 1,17 & 1,30 & $\begin{array}{c}0,89- \\
1,45 \\
\end{array}$ \\
\hline ЛФ & $\mathrm{MO} / ת$ & $\begin{array}{l}\text { Колориметричний оптимі- } \\
\text { зований кінетичний DEA } \\
\text { DGKC }\end{array}$ & 89 & 172,78 & 90,60 & $\begin{array}{c}153,70- \\
191,87\end{array}$ \\
\hline $\begin{array}{l}\text { Альфа-амі- } \\
\text { лаза }\end{array}$ & $\mathrm{MO} / л$ & $\begin{array}{l}\text { Колориметричний кінетич- } \\
\text { ний CNP-G3 }\end{array}$ & 45 & 518,50 & 197,91 & $\begin{array}{r}459,04- \\
577,96 \\
\end{array}$ \\
\hline Хлориди & ммоль/л & $\begin{array}{l}\text { Колориметричний з тіоціа- } \\
\text { натом ртуті }\end{array}$ & 12 & 102,88 & 4,05 & $\begin{array}{c}100,30- \\
105,45 \\
\end{array}$ \\
\hline Фосфор & ммоль/л & УФ з молібдатом амонія & 12 & 2,22 & 0,53 & $\begin{array}{l}1,89- \\
2,56\end{array}$ \\
\hline
\end{tabular}


Наведені відомості можуть бути використані як нові еталонні значення для клінічних біохімічних показників сироватки крові щурів-самців Вістар. Водночас варто зазначити, що результати, включені до цієї публікації, призначені лише для інформаційних цілей i не можуть бути використаними для остаточної інтерпретації будь-яких результатів токсикологічних досліджень, оскільки для порівняння найкраще підходять дані контрольної групи, які були отримані одночасно 3 даними відповідних піддослідних груп. Однак існують випадки, коли історичні контрольні показники мають неоціненне значення. Подібна інформація, зокрема, може знадобитися для пояснення того, чому конкретні статистично значущі результати дослідження не мають біологічного або токсикологічного значення. Нарешті, історичні дані також можуть бути корисними для оцінки фонової патології в популяціях тварин, що використовуються в кожній установі, або допомогти виявити певні аналітичні проблеми в лабораторії.

Звертає увагу той факт, що проаналізовані результати досліджень біохіміч- них показників сироватки крові контрольних щурів-самців лінії Вістар з 11 наукових проєктів знаходились у межах або були близькі до значень, які ми знайшли в нечисленних закордонних наукових публікаціях [7-10].

Автори даної роботи сподіваються, що установи, які використовують щурів розведення експериментально-біологічної клініки ДУ «Інститут фармакології та токсикології НАМНУ", знайдуть надану в публікації інформацію корисною.

\section{Висновки}

Збір та аналіз клінічних біохімічних показників сироватки крові щурів-самців лінії Вістар контрольних груп з 11 досліджень показав, що показники знаходяться в межах норми клінічно здорових щурів. Отримані історичні дані можна застосовувати як контрольні результати (норми) з метою оптимізації роботи в установах, що проводять експерименти 3 використанням щурів, зокрема, доклінічну оцінку ефективності та безпечності лікарських засобів та інші токсикологічні дослідження.

1. Gupta R. C. (Ed.). Biomarkers in toxicology. Academic Press, 2019. 1246 p.

2. Ramaiah S. K. A toxicologist guide to the diagnostic interpretation of hepatic biochemical parameters. Food and Chemical Toxicology. 2007. V. 45 (9). P. 1551-1557.

3. Petterino C., Argentino-Storino A. Clinical chemistry and haematology historical data in control Sprague-Dawley rats from pre-clinical toxicity studies. Experimental and Toxicologic Pathology. 2006. V. 57 (3). P. $213-219$.

4. Reference range data base for serum chemistry and hematology values in laboratory animals. S. T. Wolford, S R. A. Chroer, F. X. Gohs et al. Journal of Toxicology and Environmental Health, Part A Current Issues. 1986. V. 18 (2). P. 161-188.

5. Небыльцова О. В., Климова Ж. А., Яковенко О. К. Лабораторный справочник СИнЭВО. Киев : Доктор-Медиа, 2013. 644 с.

6. Lee B. M., Kacew S., Kim H. S. Lu's basic toxicology: fundamentals, target organs, and risk assessment. CRC press, 2017. $647 \mathrm{p}$.

7. Clinical chemistry reference database for Wistar rats and C57/BL6 mice. O. Boehm, B. Zur, A. Koch et al. Biological chemistry. 2007. V. 388 (11). P. 1255-1256.

8. Giknis M. L. A., Clifford C. B. Clinical laboratory parameters for Crl: WI (Han), March, 2008: Charles river. URL: https://www.criver.com/sites/default/files/resources/rm_rm_r_Wistar_Han_clin_lab_ parameters_08.pdf

9. The laboratory rat. M. A. Suckow, F. C. Hankenson, R. P. Wilson, P. L. Foley (Eds.). Academic Press, 2019. $1180 \mathrm{p}$.

10. Matsuzawa T., Nomura M., Unno T. Clinical Pathology Reference Ranges of Laboratory Animals. The Journal of Veterinary Medical Science. 1993. V. 55 (3). P. 351-362. https://doi.org/10.1292/jvms.55.351.

\section{Г. М. Шаяхметова, В. М. Коваленко, О. Г. Басовська, А. В. Возна Клінічні біохімічні показники сироватки крові здорових статевозрілих білих щурів-самців (ретроспективна оцінка)}

Діапазон нормальних або очікуваних гематологічних і клінічних біохімічних показників у лабораторних тварин може бути корисним інструментом для інтерпретації результатів токсикологічних 
досліджень. Однак таку інформацію часто важко знайти. Крім того, нормальні значення гематологічних і клінічних біохімічних показників можуть варіювати в різних ліній лабораторних тварин і серед тварин різних розплідників, а також певною мірою залежати від застосованих методів дослідження.

Мета дослідження - ретроспективна оцінка даних клінічної біохімії здорових (контрольні групи) щурів з розплідника ДУ «Інститут фармакології та токсикології НАМНУ». Для цього були зібрані та проаналізовані результати дослідження сироватки крові щурів-самців лінії Вістар з 11 досліджень, що останніми роками були проведені на базі ДУ «Інститут фармакології та токсикології НАМНУ». Для аналізу були використані дані, отримані на щурах-самцях, оскільки більшість досліджень була проведена саме на тваринах даної статі. Перш ніж визначити будь-які патологічні зміни в організмі піддослідних тварин слід забезпечити достовірні значення контрольного діапазону. Подібні дані можуть бути отримані від контрольних груп під час кожного дослідження. Вважається, що різні аналітичні методи, а також змінні, пов'язані з навколишнім середовищем і технікою, впливають на значення, встановлені для конкретного параметра. Оскільки дані, наведені в цій публікації, були отримані ідентичним засобом тестування, а тварини походять з одного джерела, певні ризики були мінімізовані.

Збір та аналіз клінічних біохімічних показників сироватки крові щурів-самців лінії Вістар контрольних груп з 11 досліджень показав, що показники знаходяться в межах норми клінічно здорових щурів. Отримані історичні дані можна застосовувати як контрольні результати (норми) з метою оптимізації роботи в установах, що проводять експерименти з використанням щурів, зокрема, доклінічну оцінку ефективності та безпечності лікарських засобів та інші токсикологічні дослідження. Результати, включені до цієї публікації, призначені лише для інформаційних цілей, але не для остаточної інтерпретації будь-яких результатів токсикологічних досліджень. Вони можуть бути корисними для пояснення того, чому конкретні статистично значущі результати дослідження не мають біологічного або токсикологічного значення, для оцінки фонової патології в популяціях лабораторних щурів або виявлення аналітичних проблем у лабораторії.

Ключові слова: щури, самці, клінічні біохімічні показники, сироватка крові, норма

\section{А. М. Шаяхметова, В. Н. Коваленко, А. Г. Басовская, А. В. Возная Клинические биохимические показатели сыворотки крови здоровых половозрелых белых крыс-самцов (ретроспективная оценка)}

Диапазон нормальных или ожидаемых гематологических и клинических биохимических показателей у лабораторных животных может быть полезным инструментом для интерпретации результатов токсикологических исследований. Однако подобную информацию часто трудно найти. Кроме того, нормальные значения гематологических и клинических биохимических показателей могут варьировать у разных линий лабораторных животных и среди животных разных питомников, а также в определенной степени зависеть от применяемых методов исследования.

Цель исследования - ретроспективная оценка данных клинической биохимии здоровых (контрольные группы) крыс из питомника ГУ «Институт фармакологии и токсикологии НАМНУ». Для этого были собраны и проанализированы результаты исследования сыворотки крови крыс-самцов линии Вистар из 11 исследований, которые в последние годы были проведены на базе ГУ «Институт фармакологии и токсикологии НАМНУ». Для анализа были использованы данные, полученные на крысах-самцах, поскольку большинство исследований было проведено именно на животных данного пола. Прежде чем определить любые патологические изменения в организме подопытных животных следует обеспечить достоверные значения контрольного диапазона. Подобные данные могут быть получены от контрольных групп во время каждого исследования. Считается, что различные аналитические методы, а также переменные, связанные с окружающей средой и техникой, влияют на значения, полученные для каждого конкретного параметра. Поскольку данные, приведенные в этой публикации, были получены идентичным средством тестирования, а животные происходят из одного источника, определенные риски были минимизированы.

Сбор и анализ клинических биохимических показателей сыворотки крови крыс-самцов линии Вистар контрольных групп из 11 исследований показал, что показатели находятся в пределах нормы клинически здоровых крыс. Полученные исторические данные можно применять как контрольные результаты (нормы) с целью оптимизации работы в учреждениях, которые проводят эксперименты с использованием крыс, в частности, доклиническую оценку эффективности и безопасности лекарственных средств и другие токсикологические исследования. Результаты, включенные в эту публикацию, предназначены только для информационных целей, но не для окончательной интерпретации любых результатов токсикологических исследований. Они могут быть полезными для объяснения того, почему конкретные статистически значимые результаты исследования не имеют биологического или токсикологического значения, для оценки фоновой патологии в популяциях лабораторных крыс или выявления аналитических проблем в лаборатории.

Ключевые слова: крысы, самцы, клинические биохимические показатели, сыворотка крови, норма 


\section{G. M. Shayakhmetova, V. M. Kovalenko, O. G. Basovska, A. V. Vozna Clinical biochemical parameters of healthy adult white male rats blood serum (retrospective assessment)}

The range of normal or expected hematological and clinical biochemical parameters in laboratory animals can be a useful tool for interpreting toxicological studies. However, such information is often difficult to find. Also, the normal values of hematological and clinical biochemical parameters can vary in different lines of laboratory animals and among animals of different nurseries, and also to some extent depend on the research methods used.

The purpose of this study was a retrospective assessment of the clinical biochemistry data of healthy rats (control groups) from the nursery of the SI «Institute of Pharmacology and Toxicology of the National Academy of Medical Sciences of Ukraine». Results (from 11 studies that have been conducted in recent years in SI «Institute of Pharmacology and Toxicology of the National Academy of Medical Sciences of Ukraine») on male Wistar rats serum blood investigations were collected and analyzed for this purpose. The data obtained on male rats were used for analysis because most studies were conducted on animals of this sex. Before determining any pathological changes in the organism of experimental animals, reliable control range values should be obtained. Such data can be obtained from control groups during each study. It is believed that various analytical methods, as well as variables related to the environment and technology, influence the values obtained for each particular parameter. Since the data presented in this publication was obtained by the only instrument of testing, and the animals come from the same source, certain risks were minimized.

The collection and analysis of clinical biochemical parameters of male Wistar rats' blood serum (control groups from 11 studies) showed that all parameters are within the normal range of clinically healthy rats. The historical data obtained can be used as control results (norms) to optimize studies in institutions that conduct experiments using rats, in particular, preclinical assessment of the efficacy and safety of drugs and other toxicological studies. The results included in this publication are for informational purposes only and not for the final interpretation of any toxicological research results. They can be useful in explaining why specific statistically significant results of the study have no biological or toxicological significance, for assessing the background pathology in laboratory rat populations, or for identifying analytical problems in the laboratory.

Key words: rats, males, clinical biochemical parameters, blood serum, norm

Надійшла: 1 листопада 2019 р.

Прийнята до друку: 17 грудня 2019 р.

Контактна особа: Шаяхметова Ганна Михайлівна, доктор біологічних наук, ДУ «Інститут фармакології та токсикології НАМНУ», буд. 14, вул. Антона Цедіка, м. Київ, 03057. Тел.: + 380444567865. 